\title{
Prize Awards of the Paris Academy of Sciences
}

$\mathrm{A}^{\mathrm{x}}$ the annual public moeting of the Paris Academy of Sciences, held on December 12, the prizes and grants for 1932 were awarded as follows :

Mathematics. - The Poncelet prize to Raoul Bricard, for his work in geometry; the Francoeur prize to Henri Milloux, for his work on analytical functions.

Mechanics.-A Montyon prize to Jules Haag, for his work on chronometry; the Fourneyron prize to Maurice Roy for his work in applied mechanics; the Henri de Parville prize to Joseph Pérès, for his work in hydrodynamics ; the Henry foundation to Dimitri Riabouchinsky for his work in aerodynamics and hydraulics.

Astronomy.-The Lalande prize to Abel Pourteau for his studies on the statistics of the double stars; the Damoiseau prize to Nicolas Stoyko for his studies on the measurement of time and allied problems ; the Benjamin Valz prize to Jean Dufay for his work in astronomical photometry; the Janssen medal to Alexandre Dauvillier for his studies on the aurora polaris and allied phenomena; the La Caille prize to Eugène Antoniadi for his work on planets.

Geography.-The Delalande-Guérineau prize to Ernest Benoit for his theoretical works and geodesic operations in the field ; the Gay prize to Emile Hasse for his calculations and discussions of geodesic and astronomical work carried out by the geographical service of the army; the Tehihatchef prize to Mme. Tardieu for her memoir on the ferns of Tonkin; the Binoux prize to the late Jules Hansen for his map of "L'Ancien Pays de Luxembourg".

Navigation. - The Navy prize to Pierre Malaval for his work on the resistance of materials; the Plumey prize to Henri de Leiris for his memoir entitled: "Experimental Researches on the Fatigue and Expansion of Steam Pipes".

Physics.- The L. La Caze prize to Eugène Darmois for the whole of his work; the Hébert prize to Charles Lavanchy for his work on the calculation and construction of high tension aerial cables; the Hughes prize to Emile Henriot for the whole of his work, especially on the radioactivity of the alkaline metals, the double refraction of compressed glass, high angular velocity cathode and magneto-cathode rays : the Clément Félix foundation to Gaston Dupouy for assisting his researches on magnetism.

Chemistry.-A Montyon prize (unhealthy trades) to Eugène Burlot for his work dealing with the safe handling of explosives and compressed gases ; Raymond Horclois received a mention (1,500 francs) for his researches on the application of negative catalysis for extinguishing fires; the Jecker prize to the late Marc Bridel for his work in biological chemistry ; the L. La Caze prize to Louis Hackspill for his researches in inorganic chemistry ; the Cahours foundation between Paul Thomas and Paul de Graeve for work on fermentation; the Houzeau prize to Dimitri Ivanoff for his work on Grignard syntheses.

Mineralogy and Geology.-The Fontannes prize to Gustave Sayn for his palæontological work; the Victor Raulin prize to Louis Royer for his crystallographic work; the Demolombe prize to Paul Bertrand for his work in palæobotany.

Botany.- The Desmazières prize to René Morquer for his work entitled : "Morphogenic Researches on Dactylium macrosporum" ; the Montagne prize to Gontran Hamel for his work entitled: "Chloro. phycea of the French Coasts" ; the de Coincy prize between Alfred Saint-Yves and the late John Briquet. Anatomy and Zoology.-The Cuvier prize to Pierre Fauvel for his researches on annelids; the Savigny prize to Armand Billard for his work on the hydroids of the Bay of Suez; the Thore prize to Pierre de Boissezon for his memoir entitled : "Contribution to the Study of the Biology and Histophysiology of Culex pipiens".

Medicine and Surgery.-Montyon prizes to Paul Chevallier for his work on Hodgkin's disease, Philippe Lasseur and Mlle. Andrée Dupaix for their microbiological work, Victor Veau and Mme. Suzanne Borel for their work on palatal division; honourable mentions to Jean Albert Weil for his book on the poisons of the tubercle bacillus, to Grégoire Ichok for his book on work for the sick and infirm, and to Raoul Leroy and Georges Médakovitch for their book on general paralysis and malaria therapy; citations to Henry Chabanier and Carlos Lobo-Onell for their book on diabetes and to Charles Dubois and Noèl Sollier; the Barbier prize to Stefan Jellinek for his researches on apparent death produced by electric shock; the Bréant prize (in equal parts) between Pierre Delanöe for his studies on the Moroccan spirochæte and Jean Sabrazès, Georges Jeanneney and René Mathey-Cornat for their book on bone tumours; the Godard prize to Mlle. Marthe Lamy for her book on gonococcic coxitis; the Mège prize to Henri Bouquet for his illustrated encyclopædia of medical knowledge; the Bellion prize to Edouard Imbeaux for his statistical and descriptive annual of the distribution of water and drainage in France, Algeria, Tunis, Morocco and French Colonies, Belgium, Switzerland and Luxembourg; the Baron Larrey prize to Jules Beyne, for his studies in aviators' sickness.

Physiology.-The Montyon prize to Henri Fredericq for his researches on the nerve control of the heart; the L. La Caze prize to Emile Abelous for his work in physiology, especially chemical physiology ; the Pourat prize to Louis Rapkine for his work on the energetics of development, oxido-reduction potentials in cells and the chemical processes in the course of cell division; an honourable mention to Gabriel Laniez; the Martin-Damourette prize to Paul Fleuret for his work on the nutrition of animals ; the Philipeaux prize to Paul Kucharski for his researches on audition.

History and Philosophy of Sciences.-The Binoux prize to Abel Rey, for the whole of his work on the history of science.

Works of Science.--The Henri de Parville prize between Jules Rouch, for his work on oceanography, meteorology and polar expeditions, and Georges Kimpflin, for his publications on artificial resin and the problem of heating.

Medals.-The Berthelot medal to Eugène Burlot and to Louis Hackspill.

General Prizes. - The prize founded by the State to Jacques Soula for the whole of his work; the Alhumbert prize to Francis Myard for his work on articulated systems; the Bordin prize to Gabriel Arnaud and Mme. Madeleine Arnaud for their treatise on plant pathology ; the Lallemand prize to François Kiss and Jules Botár for their work on the physiology of the nervous system ; the Serres Prize to Edouard Chatton for his work on the evolutive cycle and the 
determinism of sexuality in the Protozoa; the Vaillant prize to Maurice Gevrey for the whole of his work on partial differential equations; the Houllevigue prize to Albert Policard for his work in histophysiology and histochemistry; the Saintour prize to Albert Vandel for his work in zoology and general biology; the Lonchampt prize to Etienne Canals for his study on the physiological rôle of magnesium on plants; the Wilde prize to Ernest Chaput for his geological work; the Caméré prize to André Coyne for his work in civil engineering; the Gustave Roux prize to Pierre Bonnet for his thesis on sloughing, autotomy and regeneration in spiders with a study of the European Dolomedes; the Thorlet prize to Adolphe Richard; the Albert I of Monaco prize to Louis de Broglie for his researches in wave mechanics.

Special Foundations.--The Lannelongue foundation between Mmes. Cusco and Raphaël Rück; the Hélène Helbronner-Fould prize to Mme. Gustave Ferrié.

Prizes of the Grand Ecoles.-The Laplace prize to Jacques Desrousseaux; the L. E. Rivot prize between Jacques Desrousseaux, Georges Périneau, Jean Crussard and Jacques Aubriot.

Foundations for Scientific Research.-The Trémont foundation to Lucien Malassis for his inventions and work in connexion with calculating machines; the Gegner foundation to Wladimir Margoulis for his work in nomography with applications to aerodynamics and aviation ; the Jérôme Ponti foundation to Jean Orcel for his work in metallography and opaque minerals; the Hirn foundation to Adolphe Buhl for his studies on the transformations and invariances of multiple integrals; the Henri Becquerel foundation to Henri Galbrun for his work on the calculus of probabilities and other mathematical researches; Mme. Victor Noury foundation between André Lwoff for his work on the physiology and nutrition of the Protozoa, Louis Corbière for his work in systematic botany and his contribution to the study of Norman flora ; François Raoult for his analytical researches on rocks and Joseph Repelin for his geological work in Provence; the Henry Le Chatelier foundation to Paul Bastien for his researches on the alloys of calcium, niobium and gallium; the Roy-Vaucouloux foundation to Albert Brault for his studies on glycogen in the development of tumours, normal tissues and organised beings; the Charles Frémont foundation to $M$. and Mme. Albert Thomas for their researches on a photo-electrograph for the use of the blind.

\section{The Loutreum Foundation}

1. Researches on Definite Problems.-5,000 francs to Marcel Brillouin for carrying out numerical calculations relating to the theory of dynamic tides; 2,000 francs to Paul Dechambre for continuing his researches on the physical properties of wool; 5,000 francs to M. and Mme. Joliot-Curie for travelling and other expenses in connexion with their work on physies at the Jungfraujoch station; 2,000 franes to Gustave Lesbouyries for the study of the diseases of birds due to filtrable viruses ; 2,500 francs to Lucien Panisset and Goret for their researches on infectious anæmia of the horse ; 5,000 francs to Marcel Petit for assisting his researches in comparative anatomy ; 5,000 francs to Mme. Lucie Randoin for researches on vitamins ; 2,000 francs to Victor Robin for researches on radiodiagnosis and radiotherapy in animals ; 3,000 francs to $\mathrm{Mme}$. de Vomecourt for assisting work to be done in the New Hebrides.

2. Voyages and Explorations.-15,000 franes to Camille Arambourg as a contribution to an expedition to eastern Africa ; 9,000 franes to Auguste Chevalier as a contribution to a botanical expedition to Central Africa ; 5,000 francs to Jacques Petit for an expedition to Madagascar.

3. Purchase of Material.-8,000 franes to the Lyons National Veterinary School for the purchase of a cinematograph apparatus ; 3,000 francs to Augustin Mesnager for the purchase of an apparatus showing the distributions of strains in elastic solids; 5,000 francs to Albert Granger for the purchase of a furnace.

4. Libraries.--4,000 francs to the Toulouse National Veterinary School for its library ; 6,000 francs to the Polytechnic School for its library; 10,000 francs to the Botanical Society of France for the establishment of a card catalogue of its library.

5. Publications. $-5,000$ francs to the National and University Library of Strasbourg for preparing and printing a catalogue of periodicals ; 4,000 franes to the Astronomical Observatory of Zò-Sé, for its publications ; 9,000 franes to the National Acclimatisation Society of France for the publication of a book by (the late) Rollinat on the biology of the reptiles of central France; 5,000 francs to the widow of Jean Thomas for the publication of a book dealing with his work resulting from the expedition between the Congo and Lake Tchad.

\section{Instability of Liquid Surfaces}

$\mathrm{T}$ HE problem of the instability of the 'liquid surface' separating two media has fascinated and attracted many investigators but the complexity of the phenomenon as seen in the laboratory and in everyday life, as well as the difficulty of the mathematies, have made progress very slow in the directir a of a solution.

A reference to the instability of the surface of separation between two fluids is first found in a paper by Helmholtz ${ }^{1}$, and Kelvin ${ }^{2}$ in an investigation of the influence of wind on waves in water, supposed frictionless, discussed the conditions under which a plane surface of water becomes unstable. Adopting a suggestion due to Kelvin, Rayleigh $^{3}$ investigated the instability of such a surface and obtained results which by now are classical. To a first approximation, the system is unstable for all wave-lengths and the amplitude of an initial displacement of the form $y=a \cos k x$ increases exponentially with the time. The first approximation, however, shows no tendency in the direction of the formation of vortices, but a recent investigation by Rosenhead ${ }^{4}$ shows that the tendency towards rolling up is apparent if account is taken of second order terms in the approximation. In order to obtain the ultimate form of the surface of discontinuity, Rosenhead departs from the Rayleigh method and by means of an approximate numerical process demonstrates the formation of vortices. This method, however, does not discover the wave-length which ultimately becomes dominant in the system and so fixes the distance between successive vortices.

Banerji and Ghatage have now investigated the motion of the 'liquid surface' separating two portions 